\title{
Audience as Medium: Motivations and Emotions in News Sharing
}

\author{
ALBERTO DAFONTE-GÓMEZ \\ University of Vigo, Spain
}

\begin{abstract}
Although social media is still not the mainstream option to disseminate news for the population as a whole, social media usage for this purpose increases every year. In particular, it has become widespread among young people, and it is expected to be of paramount importance in the future. This practice alters the way news is distributed and consumed, and it directly affects the media's business model. Understanding this phenomenon is crucial to ensure the media's financial feasibility. This article uses the uses and gratifications theory to present what we know so far about the motivations behind why users share news on social media, with special reference to the role of emotion in the process.
\end{abstract}

Keywords: emotion, sharing, social media, news, viral

The way users interact in the digital environment has forced the media to transform and adapt its practices in recent years. Online content and, more recently, the boom of social media have led the press to rethink the way in which it creates and disseminates content to maintain a business model that largely depends on generating audiences to subsequently sell those audiences to advertisers.

The new scenario is mainly characterized by its frenetic and constant evolution, which forces the media to keep track of multiple sources to detect and monitor user behavioral trends. According to the Reuters Institute Digital News Report 2016 (Newman, Fletcher, Levy, \& Nielsen, 2016), three trends are currently changing the business model for press editors in the digital environment and affecting the way that news is presented and distributed: the increase in access to news on mobile devices, "the growth of distributed news consumption" (p. 8) (not on the source's site), and the widespread use of ad blockers. All of them are important enough to analyze separately, but the real research scenario arises from their interaction.

Users' rejection of intrusive online advertising and their increased consumption of content on mobile devices are two challenges whose solutions are in the hands of the media and do not depend much on external factors. The keys are finding new ways of presenting content and new models for making money and less intrusive advertising formats. However, the trend for users to access news through pathways outside media outlets-such as through social networks and instant messaging apps-means

Alberto Dafonte-Gómez: albertodafonte@uvigo.es

Date submitted: 2017-11-02

Copyright (c) 2018 (Alberto Dafonte-Gómez). Licensed under the Creative Commons Attribution Noncommercial No Derivatives (by-nc-nd). Available at http://ijoc.org. 
that the press loses control of content distribution in exchange for a multiplication of the possibilities to provide access to its news. In the old model, the media were the only senders in the news ecosystem, and they distributed content through their own outlets in a monodirectional way to mass audiences. This model is now falling apart in an environment in which "the reach of information is not simply the sum of those exposed but must take into account the probability that the recipient retransmits the information through some platform to others" (Cappella, Kim, \& Albarracín, 2015, p. 4). The current news distribution model responds to a hybrid model of circulation (Jenkins, Ford, \& Green, 2013) in which top-down and bottom-up approaches dynamically interact to determine what content is shared and disseminated in society. Although the vertical dissemination scheme in which media broadcast content to their audiences still exists, the horizontality of social media offsets this trend (Chadwick, 2011; Masip, Guallar, Suau, Ruiz-Caballero, \& Peralta, 2015).

Audiences were always considered mere recipients of "news and information created, packaged and distributed by professional media organizations" (Hermida, Fletcher, Korell, \& Logan, 2012, p. 816). However, they now have the tools to filter, select, relay, comment on, respond to, and modify content produced by the media and to create and distribute their own content.

According to Kümpel, Karnowski, and Keyling (2015), three main areas of research into the way news is shared are research on the features and motivations of users and organizations sharing news, research on the typology of content of the most widely shared items, and research on the features of the platforms through which those items are shared. These three fields are not mutually exclusive, and many studies address a combination of them.

This article shall focus on why users share news-based content on social media, with special attention to aspects related to users' psychological and emotional needs.

\section{Accessing and Participating in News on Social Media}

Online networked platforms-ecosystems including blogs, social networks, microblogs, and news aggregators-have introduced a series of social practices (sharing, liking, commenting, general conversations around news items, etc.) that have mainly a phatic function and that condition the way in which news is broadcasted and received by the social environment (Papacharissi, 2014). Audiences do not just listen to the media, but they relate to them in a much more direct way; they have adopted the-not necessarily new, of course-habit of disseminating the information that is relevant to them to their contacts. Thus, their capacity to influence those around them and to participate in the news narrative is also increased (Chadwick, 2011; Choi \& Lee, 2015; Hermida, 2010). Adapting to these new usage models through distribution and promotion-main business operations of any media enterprise (Wirtz, 2014) means making the media accessible to recipients through an optimization of content for the channels in which there is already an audience, the various social networks (Mitchell \& Holcomb, 2016; Rushkoff, 2014). The economics of attention forces the media to develop strategies to make the best of these ways of generating and disseminating information (Chadwick, 2011; Díaz-Nosty, 2013) and requires academia to study them. The report Journalism, Media and Technology Trends and Predictions (Newman, 2017) indicates that "the vast majority of publishers plan to continue to invest heavily in Facebook and to a 
lesser extent other platforms this year," (p. 10) although they are also trying to build a more direct relationship with their audiences (Anderson, 2017) and to develop plans to promote their own sites or apps (Newman, 2017).

The role of social media-and, therefore, of individuals-in the dissemination of news has been widely studied by the most relevant media institutions and research centers in recent years.

The Digital News Report 2016 (Newman et al., 2016) reported that $51 \%$ of individuals use social media as their main news source every week and that $12 \%$ claimed that social media was their most important information source, thus confirming the continued growth of social media as information source compared to other media. In the 2017 version of the report (Newman, Fletcher, Kalegeropoulos, Levy, \& Nielsen, 2017), the growth of social media to access information is noted as becoming generally stagnant compared to instant messaging applications. According to the authors, "the growth of messaging comes as an extra layer on top of social networking rather than as a replacement" (Newman et al., 2017, p. 13). However, the trend does not equally impact all markets or age groups: The report The Modern News Consumer from the Pew Research Center (Mitchell, Gottfried, Barthel, \& Shearer, 2016) claimed that digital media, apps, and social networks are already the second information source for U.S. citizens after television, and before radio and the printed press. For younger users, online media are already the first source of information, even above television (Mitchell et al., 2016; Newman et al., 2017, 2016).

Another relevant aspect of the relationship between news users and online information is the type of activity generated by the news item. Newman et al. (2016) indicate that "those with the highest levels of interest in the news, and those who access news the most frequently . . . are considerably more likely to comment or share on social media than either daily briefers or casual users" (pp. 100-101). The report defines three user profiles according to their level of interaction with the news: Proactive participators (31\% of the sample) are those who have made an original or public contribution to news coverage, reactive participators $(21 \%)$ are those who have contributed by disseminating existing news coverage or leaving feedback, and passive consumers (48\%) are those who do not actively participate in news coverage at all. The details from the Digital News Report 2016 and those from The Modern News Consumer (Mitchell et al., 2016) on the U.S. market both show that users tend to perform activities that require less reflection and personal engagement.

A further element in this scenario is introduced by the data from News Use Across Social Media Platforms 2016 from the Pew Research Center (Gottfried \& Shearer, 2016): 62\% of U.S. users access news through social media; in particular, $70 \%$ of Reddit users, $66 \%$ of Facebook users, and $59 \%$ of Twitter users access news through these networks. Various news-related activities happen on social media: "Social networks are not just important for discovery, they also encourage discussing and sharing the news. Around a quarter of news internet users (24\%) share news via social media during the average week" (Newman et al., 2016, p. 10).

News consumption and participation in the information cycle (Chadwick, 2011) through social media cannot be seen as a predominant trend for the audience as a whole; however, it is a consolidated behavior, especially among certain audiences, such as younger groups, and with immediate future 
growth: "If searching for news was the most important development of the last decade, sharing news may be among the most important of the next" (Olmstead, Mitchell, \& Rosenstiel, 2011, p. 10). This increasing trend has already introduced remarkable changes in the news production and distribution practices for online media to generate traffic (Fernández, Arrillaga, \& González, 2016). In this way, a key element of the digital media business is knowing the motivation of audiences not only to consume an item but also to comment on, share, or otherwise interact with it (Newman et al., 2016).

\section{Why We Share: Social Behavior, Personality, and Emotion}

Motives are the general disposition influencing the actions of an individual to fulfill a need (Papacharissi \& Rubin, 2000). To understand why a user shares news content produced by a media enterprise on social media, we need to understand the basics of the most primitive forms of human social behavior, aspects that predate the boom of social media. Homans (1958) understands social behavior as an exchange of (tangible or intangible) goods, such as approval or prestige, in a community. At the heart of social habits lies the exchange of intangible elements as basic social practice, the dissemination of information, stories, or knowledge created or learned from others so that "telling, sharing, and commenting on news stories has its own place within this socializing infrastructure, and new(er) technologies expand our storytelling repertoire" (Papacharissi, 2014, p. 28).

The most remarkable translation of these trends in communication theory is found in the uses and gratifications theory. This approach focuses mainly on the use of mass media but sees human need as its departure point. The idea of human need is already present in the study of interpersonal communication, but here it is seen as the underlying reason leading to motive and consequently to specific uses (Rosengren, 1974).

Although information and communications technology (ICT) progresses at a very fast pace, thus changing the media ecosystem and forms of interpersonal communication, human needs and their motives to trigger communication processes have remained, in essence, the same throughout the centuries. Papacharissi and Rubin (2000) claim that the uses and gratifications approach may help us understand, in the digital environment, "how people use technologies to negotiate their identities, social positions, and emotional lives" (p. 176).

The motives leading individuals to select and relay content can be clustered into two groups: on the one hand, those that have to do with psychological factors, and on the other, those that refer to the features of the content itself (Cappella et al., 2015).

\section{The Objectives and Needs of Individuals in the Communication Process}

We should remember that the motives of individuals are not homogeneous. Even if they can be grouped around common reference frameworks, the intensity with which they are pursued or the ways in which they are fulfilled are ultimately determined by the personality traits of each individual. 
Research on online communication has yielded a plethora of studies linking the Internet as a communication tool with different personality traits (Correa, Hinsley, \& Gil de Zúñiga, 2010; Orchard \& Fullwood, 2010). Most of these studies use either the Eysenck Personality Inventory (Eysenck \& Eysenck, 1975), which defines an individual's personality according to the dimensions extraversion/introversion and neuroticism/stability, plus the dimension psychoticism/socialization, added later, or the widely accepted Big Five, or five-factor model of personality, described by Costa and McCrae (1992) on the Revised NEO Personality Inventory, or NEO-PI-R, which uses five main personality dimensions: openness, conscientiousness, extraversion, agreeableness, and neuroticism (Gosling, Rentfrow, \& Swann, 2003; McCrae \& Costa, 1997). The studies developed so far tend to conclude that three of the five dimensions are involved in the use of Internet services and apps, such as social media or instant messaging. The three dimensions are openness, extraversion, and neuroticism (Amichai-Hamburger, 2002; AmichaiHamburger \& Ben-Artzi, 2000; Correa et al., 2010; Ehrenberg, Juckes, White, \& Walsh, 2008; Ross et al., 2009; Zywica \& Danowski, 2008).

The preexisting psychological context of individuals helps us to understand their objectives in communication. In the current context of ICT development, digital media tend to replace traditional media; however, communication motives may be the same regardless of the platform used. According to R. A. Clark and Delia (1979), three basic goals are pursued in every communication transaction: (a) instrumental objectives, or those that solve a problem or situation that generates the communication exchange; (b) interpersonal objectives, or those directed toward establishing or maintaining a relationship between the sender and recipient; and (c) identity objectives, those that relate to the sender's aim of projecting or maintaining a specific self-image. The goals presented by R. A. Clark and Delia can be easily linked to the (prior or subsequent) classification proposals around the needs that communication fulfills for individuals. One of the most widely used models in this regard is the FIRO-B (Fundamental Interpersonal Relations Orientation Behavior), suggested by Schutz (1958) and based on three dimensions that explain interpersonal behavior: inclusion, control, and affection. Generally speaking, inclusion is about the need to belong to a group, control is about the need to have influence and power over others, and affection is the need to be loved and understood.

Attention to of these areas has been unequal and sometimes overlapping in identifying concrete factors related to the needs of social interaction and those of identity building and projection (Cappella et al., 2015).

\section{Sharing Is Caring}

Historically, human beings have tended to help others who are close to them (Kurzban, BurtonChellew, \& West, 2015). From a psychological perspective, altruistic motives are those that seek an increase in the well-being of others, regardless of whether there is any cost or sacrifice associated (Batson, 2011). However, altruistic individuals may also benefit from their actions, albeit subjectively. Altruistic motives are mainly seen in the act of sharing information that is deemed useful for the user's social network (Feinberg, Willer, Stellar, \& Keltner, 2012; Kümpel et al., 2015). This can also include a prosocial component in that a user tries to build trust-based relationships with other individuals (Feinberg et al., 2012) and, at the same time, contribute to the reputation of the person sharing useful or 
entertaining information to generate reciprocity (Fehr \& Fischbacher, 2003). The report The Psychology of Sharing describes six types of "sharing personalities," including "altruists," those "primarily motivated by a desire to bring valuable content to those they care about and to let them know that they are thinking about them and that they care" (The New York Times Customer Insight Group, 2011, p. 5). This report also underlines that the most important motive for users to share content is "to improve the lives of those who consumers care about" (p. 6).

Altruism seems to be a relevant factor in sharing information online, according to research by Ho and Dempsey (2010), Oh (2012), Phelps, Lewis, Mobilio, Perry, and Raman (2004), and Sundaram, Mitra, and Webster (1998).

Entertainment is another of the most frequent motives for users to share content, and one of the most difficult aspects to analyze from an academic perspective. According to Zillmann and Bryant (1994), we could broadly define entertainment as any situation or activity that generates pleasure. This definition is clearly linked to digital media content, even if there are other gratifications attached to it too. Likewise, what Postman (1986) expressed for TV seems to be applicable to entertainment as "the natural format for the representation of all experience" (p. 87) on social media.

According to McQuail, entertainment fulfills the "users' needs for escapism, enjoyment, emotional release, and anxiety relief" (as cited in Lee \& Ma, 2012, p. 333); however, there is a difference between enjoying or browsing for entertainment on digital media (Papacharissi \& Rubin, 2000) and the motives to share it (Baek, Holton, Harp, \& Yaschur, 2011; Holton, Baek, Coddington, \& Yaschur, 2014). This last idea is revisited by Berger (2014) when he claims that "interesting, surprising, funny, or extreme" content that "makes the sharer seem interesting, funny, and in-the-know" is the content that is finally shared (p. 590). Entertainment thus becomes a bridge between these motives and those of socialization and personal image. Nevertheless, the motivation to entertain associated to the concept of emotional contagion (Hatfield, Cacioppo, \& Rapson, 1993) is explained by Guadagno, Rempala, Murphy, and Okdie (2013) as follows: "When people watch Internet video clips, they may experience the same emotions as the people in the clips, and by forwarding that clip, they anticipate that the receiver will experience similar emotions" (p. 2312). Thus, this behavior can be associated with altruistic or socializing motives.

Motives related to socialization, the needs for affection and inclusion, have to do with approval and integration (Kümpel et al., 2015). Belonging is one of the most relevant psychological influences on human behavior. A wide range of evidence shows how it affects cognitive processes, emotional patterns, and behavioral responses (Baumeister \& Leary, 1995). This dimension includes maintaining existing social bonds, getting social validation for our own actions (Guadagno et al., 2013), and establishing new relationships with people close to us through the content that we share. Such motives have an impact on the way content is searched for and processed (Lundgren \& Prislin, 1998) and also on the decision to share it (Cappella et al., 2015), as individuals try to impact on their environment too. There are two key aspects in this decision-making process: perceived usefulness and audience design.

Perceived usefulness is a concept stemming from the technology acceptance model developed by Davis in 1986 (Davis, Bagozzi, \& Warshaw, 1989) that refers to the degree to which a person believes that 
using a particular system would enhance his or her job performance or, in general terms, any aspect of his or her life. This idea of usefulness for the user as motive to use and recommend content can be found in the concept of information value-a development of the news value theory-that is defined as "a property that makes news meaningful for a large audience and that has the potential to impact others' minds or behavior" (Rudat, Buder, \& Hesse, 2014, p. 133). Nowadays, news value is not only seen from a classical or journalistic perspective but also considers the fact that the user can become a broadcaster of content, and therefore usefulness is also understood in the context of sharing news (The New York Times Customer Insight Group, 2011).

Once users have assessed the value of news for themselves, they then judge the value or usefulness of the item for their environment according to their knowledge of their audience. The concepts of audience design and expected response become relevant in this second stage. Audience design describes how senders fits the message to the knowledge, values, and interests of their audience $(H$. H. Clark \& Murphy, 1982; Rudat et al., 2014). Expected response is the assessment of how the content is going to be received by the audience in relation to the hopes for inclusion, control, or affection that senders have toward their environment (Huang, Chen, \& Wang, 2012). Scholz et al. (2017) introduced the concept of value-based virality to stress the need for self-expression and the creation of a self-image as motive to share information: "To express ourselves in positive ways and to strengthen our social bonds are the core functions of sharing" (p. 1).

\section{Sharing Is Self-Caring}

The need to belong and socialize is closely linked to the need for personal promotion through the expectations generated as anticipated reward or punishment for a particular social behavior (Kurzban et al., 2015; Lang \& Bradley, 2010).

Rewards for the prosocial behaviors of individuals by the group are understood as part of social evolution and social organization to set common values (Scholz et al., 2017), but there is also evidence of intrinsic rewards: Hepach, Vaish, and Tomasello (2017), for example, describe similar positive emotional responses in two-year-old children who have achieved something and those in situations in which they help others accomplish objectives.

According to Barasch and Berger (2014), self-presentation is one of the most widely studied motives in the literature on word-of-mouth. Altruistic motives have to do with the need to get a reputation and followers and to increase the user's status within the community (Kümpel et al., 2015). This is why people tend to share information that presents them in a positive light in front of others (Lee \& Ma, 2012); more precisely, Berger (2014) considered that impression management should motivate people to share "(a) entertaining, (b) useful, (c) self-concept relevant, (d) status related, (e) unique, (f) common ground, and $(\mathrm{g})$ accessible things while also $(\mathrm{h})$ leading incidental arousal to boost sharing and (i) affecting the valence of the content shared" (p. 590).

Status seeking through sharing can simply respond to the user's need for emotional gratification through the recognition of the community (Ho \& Dempsey, 2010) and the expectation of a social reward 
(Scholz et al., 2017). It may also respond to a material need to promote his or her work or professional image to foster his or her professional career (Baek et al., 2011; Holton et al., 2014).

Despite scientific evidence for these motives, studies such as the one by Tamir, Zaki, and Mitchell (2015) indicate that the brain generates reward stimuli when sharing information, even if it is irrelevant for the sender and there is no perceived usefulness for the recipients-delinking the behavior from pragmatic motives-and that the act of sharing information has an intrinsic value (Tamir \& Mitchell, 2012).

Advocating for one's own beliefs can also be a motivation to share content online. This is linked to the concepts of cognitive dissonance and selective exposure; selective exposure (Klapper, 1960) happens when an individual's beliefs guide his or her selection and use of media (Stroud, 2008). According to this theory, users look for information that is consistent with their prior beliefs and convictions and avoid those that trigger cognitive dissonance (Festinger, 1962; Young \& Anderson, 2017). In the current ecosystem of social media, echo chamber and filter bubble (Newman et al., 2017) are concepts that describe a situation in which users relate only to people with their same ideologies and values. Likewise, they only receive information that has been tailored to these values and preferences, both through their contacts and in their selection algorithms for their SNS content, so that their views of events are limited by filters of cognitive dissonance and selective exposure.

Later revisions of the concept of cognitive dissonance (Greenwald \& Ronis, 1978) reflect upon the conflict generated in individuals when facing opinions or beliefs that contradict their own and how this relates to their need to preserve their self-esteem rather than with a disruption of the flow of thought. Although the option to fight the information instead of avoiding it to reduce dissonance is an attitude that is well documented and has been discussed (Adams, 1961), the current communication ecosystem allows users to actively combat dissonant content by creating and disseminating news (truthful or otherwise) that supports their principles and convictions with a wider reach than ever before.

Within the logic of advocacy or lobbying, the reports Why Do People Share on Social Media? (OgilvyRED, 2014) and The Psychology Of Sharing: Why Do People Share Online? (The New York Times Customer Insight Group, 2011) both highlight promoting or supporting causes (brands) as one of the most important motives to share content on social media.

According to Berger (2014), one of the goals of word-of-mouth is persuasion, and although he is mainly referring to commercial contexts, his ideas on motives are applicable to situations of advocacy in which the user is trying to convince others of the goodness or evil of a cause, behavior, or person; this favors the sharing of extreme content with which the user may or may not agree.

\section{Sharing Is Reading?}

According to a study by Gabielkov, Ramachandran, Chaintreau, and Legout (2016) that compared the number of times tweets had been shared and data of content accessed through the links included in those tweets, $59 \%$ of the shared URLs are never clicked. 
Motives related to altruism, social relationships, and self-image are based on sharing content of value for the user's community, and one would therefore expect the user to know well what he or she shares (Huang et al., 2012) before sharing it, as the content relates to his or her own image (DafonteGómez, 2014). However, there are other ways to use content that may imply only superficial contact with summarized versions of information with just an image, a heading, a teaser, and social endorsement cues (Schäfer, Sülflow, \& Müller, 2017). They are designed for users who engage in snacking, defined by Costera Meijer and Groot Kormelink (2015) as a practice that "is not about pursuing in-depth knowledge or developed opinions, but about diversion: users consume bits and pieces of information in a relaxed, easy-going fashion to gain a sense of what is going on" (p. 670). This practice does not involve clicking on a link to access the content, but users can share and comment nonetheless.

One of the reasons for this behavior may have to do with signaling theory (Alhabash et al., 2013). This theory explains that the cost of acquiring more complete knowledge on the information (veracity of the source, vested interest, etc.) may outweigh the benefits of getting the information, something that can be applied to the costs and benefits of sharing content. When assessing such content, the most relevant aspects include the user's past experiences with the source (Lee \& Ma, 2012) or the credibility of the sender. Likewise, whenever content supports their beliefs or causes, users can take cognitive shortcuts to share and thus link their reputations to something they know only superficially.

Superficial knowledge of what is shared because of ideological reasons is the perfect breeding ground for fake news, whose senders need users as a distribution network for the content (Gu, Kropotov, \& Yarochkin, 2017). Whereas the motives of fake news producers are mainly economic or political, the motives of users sharing them must be related, among other things, to cognitive dissonance and selective exposure. A 2017 study by Buzzfeed determined that "top fake election news stories generated more total engagement on Facebook than top election stories from 19 major news outlets combined" (Silverman, 2017, para. 1). The consequences of this are a loss of trust of the average reader: U.S. citizens' trust in the media was at a historical low in 2016 since Gallup started measuring it in 1972, and the decline was more dramatic for those between 18 and 49 years of age (from 50\% in 2001 to 26\% in 2016) (Swift, 2017). Not surprisingly, one of the most important trends in the report Journalism, Media and Technology Trends and Predictions 2017 (Newman, 2017) is, precisely, the booming of fact-checking initiatives in the media, supported both by digital media and by Facebook and Google, to control the quality of the information offered to their users.

Some background thoughts about all these aspects are that, although the end behavior is the same-sharing information-the cognitive depth associated with what leads to it differs depending on the motivation behind it. Motives associated with entertainment, altruism, social integration, and even the projection of one's self-image seem to necessarily require that the content be read or viewed in its entirety before it is shared to meet the objectives of the sharer. However, motives linked to control and influence on the environment and those linked to advocacy leave a larger margin to share content after a more superficial interaction (snacking) that does not imply having checked the information beyond the headline, header, or image. 


\section{Emotion and Virality}

Apart from the personality and motivations that guide individuals in their decisions to share content online, the emotions that such content generates on users also play a vital role.

Emotions are some of the most complex aspects of human life; they share psychic and physiological features, and they affect all our actions, from cradle to the grave, even in the most imperceptible ways. Despite the fact that emotions are connatural to human beings and that they have attracted the attention of the academia since ancient times, Serrano-Puche (2016) claims that there has been increased interest in the topic in recent decades. Emotion has been analyzed from a multidisciplinary perspective, from anthropology to economics, linguistics, computer engineering, and neuroscience. The field of communication has also felt the influence of emotional factors, and in recent years, particularly in the studies on motivation to select and disseminate content by users, emotion has been researched as one of the key elements to understand this phenomenon. According to Rimé (2009), "people are attracted to emotional stories in the media, as well as in movies, novels, plays, drama, opera, songs, images, and so forth. A fascination for emotional material literally permeates everyday life" (p. 71).

The transmission of emotions has been studied both as mimesis of a certain emotional state between sender and recipient and as large-scale dissemination of information. Emotional contagion is a phenomenon that has been widely documented in the literature (Coviello et al., 2014; Doherty, 1997; Hatfield et al., 1993; Prochazkova \& Kret, 2017), and the dissemination of information about emotionally charged situations has given way to emotional broadcaster theory (Harber \& Cohen, 2005), which is based on the idea that people who have experienced important events feel the emotional need to share their experiences. The "social sharing of emotion" described by Rimé (2009) is an information phenomenon that happens "in the minutes, hours, days, even weeks and months-and sometimes years, or even an entire life-following an emotional episode" and that "entails a description of the emotional event in a sociallyshared language by the person who experienced it to another" (p. 65). These processes, described on an individual scale, take on a new dimension when they are applied to the context of media and the coconstruction of news content by users. This is what Papacharissi (2014) calls "affective news streams," which imply a combination of "subjective experience, opinion, and emotion, all sustained by and sustaining ambient news environments" (p. 34).

Much research developed around emotions in content sharing through e-mail, social media, or instant messaging apps comes from the field of viral marketing. The emotional response to advertising, for example, is one important indicator of the attitude of consumers toward a brand and a predictor of their behavior toward it (Morris, Woo, Geason, \& Kim, 2002). We know that advertisements using emotional content generate far more connections between consumers and brands than those based on rational argumentation (Micu \& Plummer, 2010). There is also neurological evidence showing that emotional content can also have effects on the attention paid to advertising and on memory (Nomura \& Mitsukura, 2015; Teixeira, 2012; Vecchiato et al., 2010, 2014). However, we must also understand how emotions influence the decisions to share content that users have been exposed to. 
The main features of viral communication are the gratuity of the content or service that is being distributed, the simplicity in redistribution, the appeal to the audience's interests in sharing, the use of existing distribution networks to convey content, and the use of external resources to disseminate the message (Welker, 2002). Viral content must therefore be designed according not only to the benefit that seeing it can bring to viewers but also to the benefit they may get from sharing it. In this regard, Dobele, Lindgreen, Beverland, Vanhamme, and van Wijk (2007) claim that "for viral marketing to work, there must be something uniquely powerful about the message, something that encourages would-be advocates to pass it on" (p. 292).

Researchers such as Berger and Milkman (2012), Dafonte-Gómez (2014), Dobele et al. (2007), Eckler and Bolls (2011), Guadagno et al. (2013), Heath, Bell, and Sternberg (2001), and Teixeira (2012) all agree on the importance of the emotions that content triggers in users to determine sharing. They also concede that viralization of content is more likely to happen if said content conveys positive emotions such as surprise or happiness. Some of these studies and others generally refer to content that generates strong, either positive or negative, emotions and arousal in individuals, be it positive or negative (Berger, 2011; Berger \& Milkman, 2012; Heath, 1996; Heath et al., 2001; Peters, Kashima, \& Clark, 2009).

The term arousal is used in various contexts with various meanings to help explain the emotional impact that a content may generate. In the behavioral context, it is used to describe the state of alertness when a stimulus is presented to the body and there is a physiological reaction related to the excitatory state of neurons. In this state, neurons tend to fire, thus increasing blood flow and the sympathetic nervous system and the organs, including the heart (Heilman, 1997). According to Berger (2011), emotions that produce higher levels of arousal tend to push individuals to share them. Berger (2011) and Berger and Milkman (2012) recognize that not only do some emotions trigger sharing but that the intensity of the emotion also plays a significant role. For example, Berger and Milkman (2012) analyzed some 7,000 news items from The New York Times and realized that items that were hopeful, inspiring, or positive were shared more often than those inducing sadness or negativity; however, items eliciting rage, anger, or outrage also generated virality. The outcomes of the study developed by Guadagno et al. (2013) on viral videos point toward some kind of "arousal hierarchy." Videos eliciting positive emotions have a higher chance of being shared, whereas videos triggering more diffuse arousal have higher chances of being shared than those that do not generate any arousal at all. Videos triggering negative emotions also have a higher chance of being shared than those that do not generate any emotion. Their study highlights fun as the emotion that generates a wish to share content. Wihbey (2014) confirms this: "The early research suggests that highly emotional content that resonates with large numbers of people has the best chance to reach across social networks and be shared by large numbers of citizens" (p. 13). Therefore, in general we could claim that positive news is most widely shared, but emotional intensity is an additional variable that increases the possibilities of an item being shared regardless of the positivity or negativity of the emotion generated.

\section{Conclusion}

The new communication ecosystem reduces the barriers to generating and distributing content online. Social media has potentially become the largest content distribution channel ever imagined. 
Data show that social media are news access and distribution channels on the rise. Among younger users, it has managed to outpace TV as the first news source. Therefore, we can claim that the news consumption patterns of tomorrow are being built today with practices that may not be widespread yet for the general population but that are already there for the audiences of the future.

Research on content sharing activities shows that emotional aspects play an important role in the decision-making process. This affects both the emotions that the content generates in the audience and the affect, identity, and social needs that individuals fulfill by sharing. However, most studies in this field take for granted that what is shared was previously read and understood, neglecting the fact that individuals may fulfill their motives by sharing links that they have not even opened. No doubt, this is an aspect that academics need to pay more attention to, especially in a world in which fake news, echo chambers, and filter bubbles have become buzzwords in any debate on journalism and public opinion.

The analysis of social behaviors in individuals must be the stepping stone for technological innovation in the media. Without the support of users, any business model, any innovative format, any new pathway for participation in the media is bound to fail. Understanding users means understanding the motives that guide their actions and condition their activities, particularly those that have a deep impact on the media, such as sharing content and thus offering distribution networks to the media while showing an emotional connection to the stories produced.

\section{References}

Adams, J. S. (1961). Reduction of cognitive dissonance by seeking consonant information. Journal of Abnormal and Social Psychology, 62(1), 74-78. doi:10.1037/h0047029

Alhabash, S., McAlister, A. R., Hagerstrom, A., Quilliam, E. T., Rifon, N. J., \& Richards, J. I. (2013). Between likes and shares: Effects of emotional appeal and virality on the persuasiveness of anticyberbullying messages on Facebook. Cyberpsychology, Behavior, and Social Networking, 16(3), 175-182. doi:10.1089/cyber.2012.0265

Amichai-Hamburger, Y. (2002). Internet and personality. Computers in Human Behavior, 18(1), 1-10. doi: 10.1016/S0747-5632(01)00034-6

Amichai-Hamburger, Y., \& Ben-Artzi, E. (2000). The relationship between extraversion and neuroticism and the different uses of the Internet. Computers in Human Behavior, 16(4), 441-449.

doi: 10.1016/S0747-5632(00)00017-0

Anderson, K. (2017). Beyond the article: Frontiers of editorial and commercial innovation. Oxford, UK: Reuters Institute for the Study of Journalism. Retrieved from http://www.digitalnewsreport.org/uncategorized/2017/beyond-article-frontiers-editorialcommercial-innovation/ 
Baek, K., Holton, A., Harp, D., \& Yaschur, C. (2011). The links that bind: Uncovering novel motivations for linking on Facebook. Computers in Human Behavior, 27(6), 2243-2248. doi:10.1016/j.chb.2011.07.003

Barasch, A., \& Berger, J. (2014). Broadcasting and narrowcasting: How audience size affects what people share. Journal of Marketing Research, 51(3), 286-299. doi:10.1509/jmr.13.0238

Batson, C. D. (2011). Altruism in humans. Oxford, UK: Oxford Scholarship Online. doi:10.1093/acprof:oso/9780195341065.001.0001

Baumeister, R. F., \& Leary, M. R. (1995). The need to belong: Desire for interpersonal attachments as a fundamental human motivation. Psychological Bulletin, 117(3), 497-529.

Berger, J. (2011). Arousal increases social transmission of information. Psychological Science, 22(7), 891-893. doi:10.1177/0956797611413294

Berger, J. (2014). Word of mouth and interpersonal communication: A review and directions for future research. Journal of Consumer Psychology, 24(4), 586-607. doi:10.1016/j.jcps.2014.05.002

Berger, J., \& Milkman, K. L. (2012). What makes online content viral? Journal of Marketing Research, 49(2), 192-205. doi:http://dx.doi.org/10.1509/jmr.10.0353

Cappella, J. N., Kim, H. S., \& Albarracín, D. (2015). Selection and transmission processes for information in the emerging media environment: Psychological motives and message characteristics. Media Psychology, 18(3), 396-424. doi:10.1080/15213269.2014.941112

Chadwick, A. (2011). The political information cycle in a hybrid news system: The British prime minister and the "Bullygate" affair. The International Journal of Press/Politics, 16(1), 3-29. doi: $10.1177 / 1940161210384730$

Choi, J., \& Lee, J. K. (2015). Investigating the effects of news sharing and political interest on social media network heterogeneity. Computers in Human Behavior, 44, 258-266. doi: 10.1016/j.chb.2014.11.029

Clark, H. H., \& Murphy, G. L. (1982). Audience design in meaning and reference. Advances in Psychology, 9, 287-299. doi:10.1016/S0166-4115(09)60059-5

Clark, R. A., \& Delia, J. G. (1979). Topoi and rhetorical competence. Quarterly Journal of Speech, 65(2), 187-206. doi:10.1080/00335637909383470

Correa, T., Hinsley, A. W., \& Gil de Zúñiga, H. (2010). Who interacts on the Web? The intersection of users' personality and social media use. Computers in Human Behavior, 26(2), 247-253. doi:10.1016/j.chb.2009.09.003 
Costa, P. T., \& McCrae, R. R. (1992). Four ways five factors are basic. Personality and Individual Differences, 13(6), 653-665. doi:10.1016/0191-8869(92)90236-I

Costera Meijer, I., \& Groot Kormelink, T. (2015). Checking, sharing, clicking and linking. Digital Journalism, 3(5), 664-679. doi:10.1080/21670811.2014.937149

Coviello, L., Sohn, Y., Kramer, A. D. I., Marlow, C., Franceschetti, M., Christakis, N. A., \& Fowler, J. H. (2014). Detecting emotional contagion in massive social networks. PLoS ONE, 9(3), e90315. doi: 10.1371/journal.pone.0090315

Dafonte-Gómez, A. (2014). The key elements of viral advertising: From motivation to emotion in the most shared videos. Comunicar, 22(43), 199-207. doi:10.3916/C43-2014-20

Davis, F. D., Bagozzi, R. P., \& Warshaw, P. R. (1989). User acceptance of computer technology: A comparison of two theoretical models. Management Science, 35(8), 982-1003. doi: $10.1287 / \mathrm{mnsc}$.35.8.982

Díaz-Nosty, B. (2013). La prensa en el nuevo ecosistema informativo: iQue paren las rotativas! [The press in the new information ecosystem: Stop the presses!]. Barcelona, Spain: Ariel/Fundación Teléfónica.

Dobele, A., Lindgreen, A., Beverland, M., Vanhamme, J., \& van Wijk, R. (2007). Why pass on viral messages? Because they connect emotionally. Business Horizons, 50(4), 291-304. doi:10.1016/j.bushor.2007.01.004

Doherty, R. W. (1997). The emotional contagion scale: A measure of individual differences. Journal of Nonverbal Behavior, 21(2), 131-154.

Eckler, P., \& Bolls, P. (2011). Spreading the virus: Emotional tone of viral advertising and its effect on forwarding intentions and attitudes. Journal of Interactive Advertising, 11(2), 1-11. doi: $10.1080 / 15252019.2011 .10722180$

Ehrenberg, A., Juckes, S., White, K. M., \& Walsh, S. P. (2008). Personality and self-esteem as predictors of young people's technology use. Cyberpsychology \& Behavior, 11(6), 739-741. doi: $10.1089 / \mathrm{cpb} .2008 .0030$

Eysenck, H. J., \& Eysenck, S. E. G. (1975). Manual: Eysenck personality inventory. San Diego, CA: Educational and Industrial Testing Service.

Fehr, E., \& Fischbacher, U. (2003). The nature of human altruism. Nature, 425(6960), 785-791. doi: $10.1038 /$ nature 02043 
Feinberg, M., Willer, R., Stellar, J., \& Keltner, D. (2012). The virtues of gossip: Reputational information sharing as prosocial behavior. Journal of Personality and Social Psychology, 102(5), 1015-1030. doi: $10.1037 / a 0026650$

Fernández, S. P., Arrillaga, I. L., \& González, D. G. (2016). European newspapers' digital transition: New products and new audiences. Comunicar, 24(46), 27-36. doi:10.3916/C46-2016-03

Festinger, L. (1962). A theory of cognitive dissonance. Stanford, CA: Stanford University Press.

Gabielkov, M., Ramachandran, A., Chaintreau, A., \& Legout, A. (2016). Social clicks: What and who gets read on Twitter? Paper presented at the ACM SIGMETRICS/IFIP Performance 2016, Juan-LesPins, France. Retrieved from https://hal.inria.fr/hal-01281190/document

Gosling, S. D., Rentfrow, P. J., \& Swann, W. B. (2003). A very brief measure of the Big-Five personality domains. Journal of Research in Personality, 37, 504-528.

Gottfried, J., \& Shearer, E. (2016, May 26). News use across social media platforms 2016. Retrieved from http://www.journalism.org/2016/05/26/news-use-across-social-media-platforms-2016/

Greenwald, A. G., \& Ronis, D. L. (1978). Twenty years of cognitive dissonance: Case study of the evolution of a theory. Psychological Review, 85(1), 53-57. doi:10.1037/0033-295X.85.1.53

Gu, L., Kropotov, V., \& Yarochkin, F. (2017). The fake news machine: How propagandists abuse the Internet and manipulate the public (TrendLabs research paper). TrendLabs. Retrieved from https://documents.trendmicro.com/assets/white_papers/wp-fake-news-machine-howpropagandists-abuse-the-internet.pdf?_ga=2.117063430.1073547711.14973555701028938869.1495462143

Guadagno, R. E., Rempala, D. M., Murphy, S., \& Okdie, B. M. (2013). What makes a video go viral? An analysis of emotional contagion and Internet memes. Computers in Human Behavior, 29(6), 2312-2319. doi:10.1016/j.chb.2013.04.016

Harber, K. D., \& Cohen, D. J. (2005). The emotional broadcaster theory of social sharing. Journal of Language and Social Psychology, 24(4), 382-400. doi:10.1177/0261927X05281426

Hatfield, E., Cacioppo, J. T., \& Rapson, R. L. (1993). Emotional Contagion. Current Directions in Psychological Science, 2(3), 96-100. doi:10.1111/1467-8721.ep10770953

Heath, C. (1996). Do people prefer to pass along good or bad news? Valence and relevance of news as predictors of transmission propensity. Organizational Behavior and Human Decision Processes, 68(2), 79-94. 
Heath, C., Bell, C., \& Sternberg, E. (2001). Emotional selection in memes: The case of urban legends. Journal of Personality and Social Psychology, 81(6), 1028. doi:10.1037/0022-3514.81.6.1028

Heilman, K. M. (1997). The neurobiology of emotional experience. Journal of Neuropsychiatry and Clinical Neurosciences, 9(3), 439-448. doi:10.1176/jnp.9.3.439

Hepach, R., Vaish, A., \& Tomasello, M. (2017). The fulfillment of others' needs elevates children's body posture. Developmental Psychology, 53(1), 100-113. doi:10.1037/dev0000173

Hermida, A. (2010). From TV to Twitter: How ambient news became ambient journalism. M/C Journal, 13(2). Retrieved from http://journal.media-culture.org.au/index.php/mcjournal/article/view/220

Hermida, A., Fletcher, F., Korell, D., \& Logan, D. (2012). Share, like, recommend. Journalism Studies, 13(5-6), 815-824. doi:10.1080/1461670X.2012.664430

Ho, J. Y. C., \& Dempsey, M. (2010). Viral marketing: Motivations to forward online content. Journal of Business Research, 63(9-10), 1000-1006. doi:10.1016/j.jbusres.2008.08.010

Holton, A. E., Baek, K., Coddington, M., \& Yaschur, C. (2014). Seeking and sharing: Motivations for linking on Twitter. Communication Research Reports, 31(1), 33-40.

doi: $10.1080 / 08824096.2013 .843165$

Homans, G. (1958). Social behavior as exchange. American Journal of Sociology, 63(6), 597-606.

Huang, J., Chen, R., \& Wang, X. (2012). Factors influencing intention to forward short Internet videos. Social Behavior and Personality: An International Journal, 40(1), 5-14.

doi: $10.2224 /$ sbp. 2012.40 .1 .5

Jenkins, H., Ford, S., \& Green, J. (2013). Spreadable media: Creating value and meaning in a networked culture. New York, NY: New York University Press.

Klapper, J. T. (1960). The effects of mass communication. Glencoe, IL: Free Press.

Kümpel, A. S., Karnowski, V., \& Keyling, T. (2015). News sharing in social media: A review of current research on news sharing users, content, and networks. Social Media + Society, 1(2).

doi: $10.1177 / 2056305115610141$

Kurzban, R., Burton-Chellew, M. N., \& West, S. A. (2015). The evolution of altruism in humans. Annual Review of Psychology, 66, 575-599. doi:10.1146/annurev-psych-010814-015355

Lang, P. J., \& Bradley, M. M. (2010). Emotion and the motivational brain. Biological Psychology, 84(3), 437-450. doi:10.1016/j.biopsycho.2009.10.007 
Lee, C. S., \& Ma, L. (2012). News sharing in social media: The effect of gratifications and prior experience. Computers in Human Behavior, 28(2), 331-339. doi:10.1016/j.chb.2011.10.002

Lundgren, S. R., \& Prislin, R. (1998). Motivated cognitive processing and attitude change. Personality and Social Psychology Bulletin, 24(7), 715-726. doi:10.1177/0146167298247004

Masip, P., Guallar, J., Suau, J., Ruiz-Caballero, C., \& Peralta, M. (2015). News and social networks: Audience behavior. El Profesional de La Información, 24(4), 363-370. doi:10.3145/epi.2015.jul.02

McCrae, R. R., \& Costa, P. T., Jr. (1997). Personality trait structure as a human universal. American Psychologist, 52(5), 509-516. doi:10.1037/0003-066X.52.5.509

Micu, A. C., \& Plummer, J. T. (2010). Measurable emotions: How television ads really work. Journal of Advertising Research, 50(2), 137-153. doi:10.2501/S0021849910091300

Mitchell, A., Gottfried, J., Barthel, M., \& Shearer, E. (2016, July 7). The modern news consumer. Retrieved from http://www.journalism.org/2016/07/07/the-modern-news-consumer/

Mitchell, A., \& Holcomb, J. (2016, June 15). State of the news media 2016. Retrieved from http://www.journalism.org/2016/06/15/state-of-the-news-media-2016/

Morris, J. D., Woo, C., Geason, J. A., \& Kim, J. (2002). The power of affect: Predicting intention. Journal of Advertising Research, 42(3), 7-17. doi:10.2501/JAR-42-3-7-17

Newman, N. (2017). Journalism, media and technology: Trends and predictions 2017. Oxford, UK: Reuters Institute for the Study of Journalism. Retrieved from http://www.digitalnewsreport.org/publications/2017/journalism-media-technology-predictions2017/

Newman, N., Fletcher, R., Kalegeropoulos, A., Levy, D. A. L., \& Nielsen, R. K. (2017). Reuters Institute Digital News Report 2017. Oxford, UK: Reuters Institute for the Study of Journalism. Retrieved from https://reutersinstitute.politics.ox.ac.uk/sites/default/files/Digital\%20News \%20Report\%202017\%20web_0.pdf

Newman, N., Fletcher, R., Levy, D. A. L., \& Nielsen, R. K. (2016). Reuters Institute Digital News Report 2016. Oxford, UK: Reuters Institute for the Study of Journalism. Retrieved from http://reutersinstitute.politics.ox.ac.uk/sites/default/files/research/files/Digital\%2520News\%252 OReport\%25202016.pdf

The New York Times Customer Insight Group. (2011). The psychology of sharing: Why do people share online? New York, NY: The New York Times Company. Retrieved from http://www.iab.net/media/file/POSWhitePaper.pdf 
Nomura, T., \& Mitsukura, Y. (2015). Extraction of unconscious emotions while watching TV commercials (pp. 368-373). Presented at the IECON 2015-41st Annual Conference of the IEEE Industrial Electronics Society, Yokohama, Japan. doi:10.1109/IECON.2015.7392127

OgilvyRED. (2014, August). Why do people share on social media? Global survey results: Social media. Retrieved from https://www.slideshare.net/socialogilvy/why-do-people-share-on-social-mediaglobal-survey-results

Oh, S. (2012). The characteristics and motivations of health answerers for sharing information, knowledge, and experiences in online environments. Journal of the Association for Information Science and Technology, 63(3), 543-557. doi:10.1002/asi.21676

Olmstead, K., Mitchell, A., \& Rosenstiel, T. (2011, May 9). Navigating news online. Retrieved from http://www.journalism.org/2011/05/09/navigating-news-online/

Orchard, L. J., \& Fullwood, C. (2010). Current perspectives on personality and Internet use. Social Science Computer Review, 28(2), 155-169. doi:10.1177/0894439309335115

Papacharissi, Z. (2014). Toward new journalism(s): Affective news, hybridity, and liminal spaces. Journalism Studies, 16(1), 27-40. doi:10.1080/1461670X.2014.890328

Papacharissi, Z., \& Rubin, A. M. (2000). Predictors of Internet use. Journal of Broadcasting \& Electronic Media, 44(2), 175-196. doi:10.1207/s15506878jobem4402_2

Peters, K., Kashima, Y., \& Clark, A. (2009). Talking about others: Emotionality and the dissemination of social information. European Journal of Social Psychology, 39(2), 207-222. doi:10.1002/ejsp.523

Phelps, J. E., Lewis, R., Mobilio, L., Perry, D., \& Raman, N. (2004). Viral marketing or electronic word-ofmouth advertising: Examining consumer responses and motivations to pass along email. Journal of Advertising Research, 44(4), 333-348. doi:10.1017/S0021849904040371

Postman, N. (2006). Amusing ourselves to death: Public discourse in the age of show business (20th anniversary ed.). New York, NY: Penguin.

Prochazkova, E., \& Kret, M. E. (2017). Connecting minds and sharing emotions through mimicry: A neurocognitive model of emotional contagion. Neuroscience and Biobehavioral Reviews, 80, 99114. doi:10.1016/j.neubiorev.2017.05.013

Rimé, B. (2009). Emotion elicits the social sharing of emotion: Theory and empirical review. Emotion Review, 1(1), 60-85. doi:10.1177/1754073908097189 
Rosengren, K. (1974). Uses and gratifications: A paradigm outlined. In O. Blumler \& E. Katz, The uses of mass communications (pp. 269-286). Beverly Hills, CA: SAGE Publications.

Ross, C., Orr, E. S., Sisic, M., Arseneault, J. M., Simmering, M. G., \& Orr, R. R. (2009). Personality and motivations associated with Facebook use. Computers in Human Behavior, 25(2), 578-586. doi:10.1016/j.chb.2008.12.024

Rudat, A., Buder, J., \& Hesse, F. W. (2014). Audience design in Twitter: Retweeting behavior between informational value and followers' interests. Computers in Human Behavior, 35, 132-139. doi: $10.1016 /$ j.chb.2014.03.006

Rushkoff, D. (2014, April). On the economy of likes. Rhapsody Magazine. Retrieved from http://inklive.com/emagazines/united-rhapsody/1628/april-2014/files/assets/basic-html/page30.html

Schäfer, S., Sülflow, M., \& Müller, P. (2017). The special taste of snack news: An application of niche theory to understand the appeal of Facebook as a news source. First Monday, 22(4). doi: $10.5210 /$ fm.v22i4.7431

Scholz, C., Baek, E. C., O’Donnell, M. B., Kim, H. S., Cappella, J. N., \& Falk, E. B. (2017). A neural model of valuation and information virality. Proceedings of the National Academy of Sciences, 114(11), 2881-2886. doi:10.1073/pnas.1615259114

Schutz, W. C. (1958). FIRO: A three-dimensional theory of interpersonal behavior. APA PSycNET. Retrieved from http://psycnet.apa.org/psycinfo/1959-02479-000

Serrano-Puche, J. (2016). Internet and emotions: New trends in an emerging field of research. Comunicar, 24(46), 19-26. doi:10.3916/C46-2016-02

Silverman, C. (2017, November 16). This analysis shows how viral fake election news stories outperformed real news on Facebook. Buzzfeed. Retrieved from https://www.buzzfeed.com/ craigsilverman/viral-fake-election-news-outperformed-real-news-on-facebook

Stroud, N. J. (2008). Media use and political predispositions: Revisiting the concept of selective exposure. Political Behavior, 30(3), 341-366. doi:10.1007/s11109-007-9050-9

Sundaram, D. S., Mitra, K., \& Webster, C. (1998). Word-of-mouth communications: A motivational analysis. Advances in Consumer Research, 25(1), 527-531. Retrieved from http://acrwebsite.org/volumes/8208/volumes/v25/NA-25

Swift, A. (2017, September 14). Americans' trust in mass media sinks to new low. Gallup News. Retrieved from http://www.gallup.com/poll/195542/americans-trust-mass-media-sinks-new-low.aspx 
Tamir, D. I., \& Mitchell, J. P. (2012). Disclosing information about the self is intrinsically rewarding. Proceedings of the National Academy of Sciences, 109(21), 8038-8043. doi:10.1073/pnas.1202129109

Tamir, D. I., Zaki, J., \& Mitchell, J. P. (2015). Informing others is associated with behavioral and neural signatures of value. Journal of Experimental Psychology. General, 144(6), 1114-1123. doi: $10.1037 / x g e 0000122$

Teixeira, T. (2012). The new science of viral ads. Harvard Business Review, 90(3), 25-27.

Vecchiato, G., Astolfi, L., De Vico, F., Cincotti, F., Mattia, D., Salinari, S., . . Babiloni, F. (2010). Changes in brain activity during the observation of TV commercials by using EEG, GSR and HR measurements. Brain Topography, 23(2), 165-179. doi:10.1007/s10548-009-0127-0

Vecchiato, G., Di, F., Maglione, A. G., Cherubino, P., Kong, W., Trettel, A., \& Babiloni, F. (2014). An electroencephalographic peak density function to detect memorization during the observation of TV commercials. Paper presented at the 2014 36th Annual International Conference of the IEEE Engineering in Medicine and Biology Society, EMBC 2014, Chicago, IL. doi:10.1109/EMBC.2014.6945231

Welker, C. B. (2002). The paradigm of viral communication. Information Services \& Use, 22(1), 3-8.

Wihbey, J. (2014). The challenges of democratizing news and information: Examining data on social media, viral patterns and digital influence (SSRN Scholarly Paper No. ID 2466058). Rochester, NY: Social Science Research Network. Retrieved from http://papers.ssrn.com/abstract $=2466058$

Wirtz, B. W. (2014). Business models, value chains and competencies in media markets: A service system perspective. Palabra Clave, 17(4), 1041-1065. doi:10.5294/pacla.2014.17.4.3

Young, D. G., \& Anderson, K. (2017). Media diet homogeneity in a fragmented media landscape. Atlantic Journal of Communication, 25(1), 33-47. doi:10.1080/15456870.2017.1251434

Zillmann, D., \& Bryant, J. (1994). Entertainment as Media Effect. In J. Bryant \& D. Zillmann (Eds.), Media effects: Advances in theory and research (pp. 437-462). Hillsdale, NJ: Erlbaum.

Zywica, J., \& Danowski, J. (2008). The faces of Facebookers: Investigating social enhancement and social compensation hypotheses; predicting Facebook and offline popularity from sociability and selfesteem, and mapping the meanings of popularity with semantic networks. Journal of ComputerMediated Communication, 14(1), 1-34. doi:10.1111/j.1083-6101.2008.01429.x 